\title{
Quality of life of patients with an intestinal stoma constructed in the course of treatment of rectal and sigmoid colon cancer
}

\section{Jakość życia chorych ze stomią jelitową wyłonioną w przebiegu leczenia raka odbytnicy i esicy}

\author{
Monika Pierzak ${ }^{1}$, Stanisław Głuszek $k^{2,3}$, Aneta Kozieł' ${ }^{1}$, Martyna Wychowaniec ${ }^{1}$ \\ 1Doctoral Studies, Faculty of Medicine and Health Sciences, Jan Kochanowski University, Kielce, Poland \\ Head of the Faculty: Prof. Stanisław Głuszek MD, PhD \\ ${ }^{2}$ Department of Surgery and Surgical Nursing with Research Laboatory, Institute of Medical Sciences, Faculty of Medicine \\ and Health Science, Jan Kochanowski University, Kielce, Poland \\ Head of the Department: Prof. Stanisław Głuszek MD, PhD \\ ${ }^{3}$ Clinical Department of General, Oncological and Endocrinological Surgery, Regional Hospital, Kielce, Poland \\ Head of the Department: Prof. Stanisław Głuszek MD, PhD
}

Key words: cancer, stoma, quality of life.

Słowa kluczowe: rak, stomia, jakość życia.

\begin{abstract}
Introduction: The increased human life span is accompanied by a growing number of carcinomas, including colorectal cancer. This is due not only to genetic conditioning but also exposure to hazardous factors present in the environment. A stoma is the consequence of surgical treatment of colorectal cancer.

Aim of the research: The objective of the study is to determine the level of quality of life of patients with an intestinal stoma, which would allow an evaluation of the effect of a stoma on the bio-psychosocial functioning of patients, as well as precise specification of discomfort of living with a stoma.

Material and methods: The study was conducted during the period from January to April 2015, in the Surgical Clinic of the Regional Cancer Centre in Kielce, and included 102 patients with a stoma, aged 35-75. The study group included 65 males and 37 females, with a stoma constructed mainly from the sigmoid colon or rectum within various periods after surgical treatment. The method of a diagnostic survey was applied, and a questionnaire was selected as the research instrument. The patients were both rural and urban inhabitants. Statistical calculations were performed using the $\chi^{2}$ test.

Results: Based on the analysis of the results of the study, the quality of life of patients with an intestinal stoma formed in the course of surgical treatment of sigmoid colon and rectal cancer was investigated. The quality of life of patients is at a medium level (neither good nor poor).

Conclusions: The quality of life of patients with an intestinal stoma depends on the degree of acceptance of the stoma and the present body image. The quality of life of patients with an intestinal stoma depends on the duration of the disease and of the stoma. There is no relationship between the degree of acceptance of the stoma by the patient and support received from family and friends. The stoma affects the quality of the sex life of patients.
\end{abstract}

\section{Streszczenie}

Wprowadzenie: Wraz ze wzrostem długości ludzkiego życia zwiększa się liczba nowotworów, w tym nowotworów jelita grubego. Spowodowane jest to nie tylko uwarunkowaniami genetycznymi, lecz także narażeniem na czynniki szkodliwe znajdujące się w środowisku. Stomia jest wynikiem chirurgicznego leczenia raka jelita grubego.

Cel pracy: Określenie poziomu jakości życia pacjentów ze stomią jelitową, co pozwoli na ocenę wpływu stomii na biopsychospołeczne funkcjonowanie chorych, a także na precyzyjne określenie dyskomfortu życia ze stomią.

Materiał i metody: Badania przeprowadzono od stycznia do kwietnia 2015 r. w Świętokrzyskim Centrum Onkologii w Kielcach w Poradni Chirurgicznej. Objęto nimi 102 osoby z wyłonioną stomią jelitową w wieku od 35 do 75 lat. W grupie badanej znalazło się 65 mężczyzn i 37 kobiet. Były to osoby z kolostomią wyłonioną głównie na esicy lub odbytnicy, w różnym okresie po leczeniu operacyjnym. Zastosowano metodę sondażu diagnostycznego, a jako narzędzie badawcze wybrano kwestionariusz ankiety. Byli to mieszkańcy zarówno miasta, jak i wsi. Do obliczeń statystycznych zastosowano test $\chi^{2}$.

Wyniki: Na podstawie analizy wyników badań zbadano jakość życia chorych ze stomią jelitową wyłonioną w przebiegu leczenia chirurgicznego raka esicy i odbytnicy. Jakość życia pacjentów kształtuje się na poziomie średnim (ani dobra, ani zła). 
Wnioski: Jakość życia pacjentów z wyłonioną stomia jelitową zależy od stopnia akceptacji stomii i obecnego wyglądu ciała. Jakość życia chorych, u których wyłoniono stomię jelitową, jest uzależniona od czasu trwania choroby i długości życia z wyłonioną stomią. Nie stwierdzono zależności pomiędzy stopniem akceptacji stomii przez chorego a wsparciem otrzymanym od rodziny oraz przyjaciół. Stomia wpływa na jakość życia seksualnego chorych.

\section{Introduction}

In recent years, an increased interest has been observed in the 'quality of life' of patients with various types of diseases. Such a great interest in this scope of problems is closely related to the new concept or ideology of medicine which covers the recognition of patient care responsible for the whole patient, the so-called holistic model, i.e. extending the patient's life expectancy in the biological sense, as well as providing assistance in order to make this life more active and closer to that from before the disease [1].

The concept of the quality of life (QoL) has been taken from the social sciences. In the literature, many definitions of this term are encountered. This is due to the fact that the quality of life is subject to the effect of many factors. In general, the quality of life comprises the whole physical, emotional, social and sexual status [2]. The quality of life is a multidimensional, subjective and dynamic concept. Multidimensionality is related to the major domains exerting an effect on humans - physical, social, and psychological. Subjectivity, indicated by the quality of life, means that only the patient can evaluate the level of wellbeing and satisfaction, whereas dynamism refers to the fluency and variability in time; therefore, it is necessary to consider the correctness, regularity and promptness of measurements of the quality of life [3]. Use of the term quality of life in medicine concerns both the objective and subjective state of the patient [4]. The most important factor which decides about the quality of life is, and must be, the state of health. Thus, the quality of life is a complex method of evaluation by an individual of their own physical health, emotional status, independence, and degree of dependence on, as well as relations with, the environment, personal convictions and beliefs [5]. With respect to the quality of medical care, the study of the quality of life comes down to answering the question: to what extent are the patient's hopes and expectations satisfied by modern medicine? [6]. Among patients with a stoma, there are people of various ages. The overall state of the patient with a stoma depends on the cause of the procedure, advancement of the pathology, correctness of the preparation for surgery, and the quality of post-operative care. Functioning with a stoma affects the bio-psychosocial functioning of the patient. Individuals with a stoma are afraid of functioning in society and are concerned about physical suffering, loss of human dignity, social status, 'possibility to fulfil life dreams', as well as occupational activity. Life with a stoma exerts an effect on the quality of life of patients considering the physical, psychological, and social aspects. The results of studies presented below indicate the most important causes of dysfunction of living with an intestinal stoma [7, 8].

\section{Aim of the research}

The objective of the study is to determine the quality of life of patients with an intestinal stoma, which will allow evaluation of the effect of the stoma on the bio-psychosocial functioning of patients, as well as precise determination of discomfort of living with a stoma.

\section{Material and methods}

The study was conducted during the period from January to April 2015, in the Surgical Clinic of the Regional Cancer Centre in Kielce. The patients were informed concerning anonymity of the conducted study.

\section{Characteristics of the study group}

The study included 102 patients with an intestinal stoma, aged $35-75,65$ male and 37 female. The patients had a stoma derived mainly from the sigmoid colon or rectum within various periods after surgical treatment. These were men and women with various levels of education - primary incomplete, primary, primary vocational, secondary school, and university education - who lived in both rural and urban areas. The respondents also differed according to material status; some of them were occupationally active, while others lived on health benefits, old pension, or were unemployed.

The main research question posed in the present study was as follows: What is the level of the quality of life of patients with intestinal stoma formed in the course of surgical treatment of sigmoid colon or rectal cancer?

The following secondary questions resulted from the main question:

1. In what way does acceptance of the disease and stoma affect the quality of life?

2. To what degree does support from family and friends affect the quality of life with an intestinal stoma?

3. How does the occupational situation affect the quality of life with an intestinal stoma?

4. In what way does the patients' subjective approach to life affect the level of the quality of life?

5. To what degree does functioning with a stoma affect the quality of sex life of patients? 


\section{Research hypotheses}

1. There is a relationship between the quality of life of patients with a stoma and occupational activity.

2. The quality of life of patients with a stoma depends on the duration of the disease and duration of living with a stoma.

3. There is a relationship between quality of life of patients with an intestinal stoma and degree of acceptance of own body image, and skills to find oneself in a new life situation, considering aspects of family and occupational life.

4. There is a relationship between the quality of life of patients with a stoma and their marital status.

5. There is a relationship between the quality of life of patients with a stoma and support provided by family, friends, acquaintances, support group, and superior.

The study was carried out by the method of a diagnostic survey, using a questionnaire technique. The research instrument was a questionnaire designed by the author, and a standardized questionnaire investigating the quality of life of patients with an intestinal stoma, the Stoma QoL. The quality of life questionnaire Stoma QoL is a simple, clinically validated questionnaire designed specially for patients with a stoma for daily use, for work with the patient, and for research work. It was developed by nurses, and its task is to investigate the quality of life of patients with a stoma. The items in the Stoma QoL are the result of many surveys conducted with persons with an intestinal stoma in many countries in order to indicate the questions referring to the quality of life of this population group. The questions concern the following: sleep, intimate relationships, family relations and relations with significant others and friends, as well as relations with other people in society. The questionnaire contains 20 questions, e.g. 'I am worried that the stoma bag will come off'. All answers to the questions must fall into the 4-score scale. The replies are as follows: 'Always', 'Sometimes', 'Rarely', and 'Not at all'. Each individual question may be ascribed a minimum score of 1 , and a maximum score of 4 ; a score of 2 or

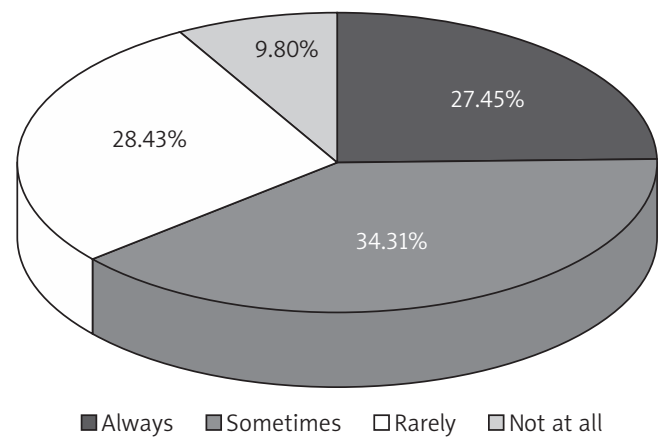

Figure 1 . Because of my stoma I feel sexually unattractive
3 may also be given. The maximum possible score is 80 , while the minimum possible score is 20 [9].

\section{Statistical analysis}

The results obtained by the respondents were calculated from the quantitative aspect, and subsequently presented in the form of tables and graphs. The data obtained in the study are a basis for the analysis presented in the subsequent section of the report. Statistical analysis was performed using the $\chi^{2}$ test.

\section{Results}

Among 102 patients participating in the study, 65 were female (63.73\%) and 37 male (36.27\%). 43.14\% of respondents $(n=44)$ were aged 50-60, 23.53\% $(n=24)$ were aged $40-50,13.73 \%(n=14)$ were aged $60-70,13.73 \%(n=14)$ were aged $70-80$, and $5.88 \%$ $(n=6)$ were aged 30-40. Among the examined patients, $51.96 \%(n=53)$ lived in rural areas, $37.25 \%$ $(n=38)$ were inhabitants of cities with a population up to 100,000 , whereas $10.78 \%(n=11)$ lived in cities with a population of over 100,000.

In the group examined, $34.31 \%$ of respondents $(n=35)$ 'sometimes' feel sexually unattractive, and $27.45 \%$ ( $n=28)$ 'always' feel sexually unattractive. The above data show that the stoma exerts an effect on the level of self-reported sexual attractiveness (Figure 1).

The analysis shows that $47.06 \%$ of respondents $(n=48)$ are 'sometimes' ashamed of their own body, while $23.53 \%(n=24)$ are 'always' ashamed (Figure 2).

Analysis of results indicates that as many as $53.92 \%$ of respondents are 'sometimes' worried that their condition is a burden for those who are close to them (Figure 3).

As many as $53.92 \%$ of stoma patients examined admit that the stoma hinders their being with others (Figure 4).

\section{Verification of the quality of life of patients using standardized questionnaire scoring key}

The quality of life of patients with an intestinal stoma constructed in the course of treatment of the

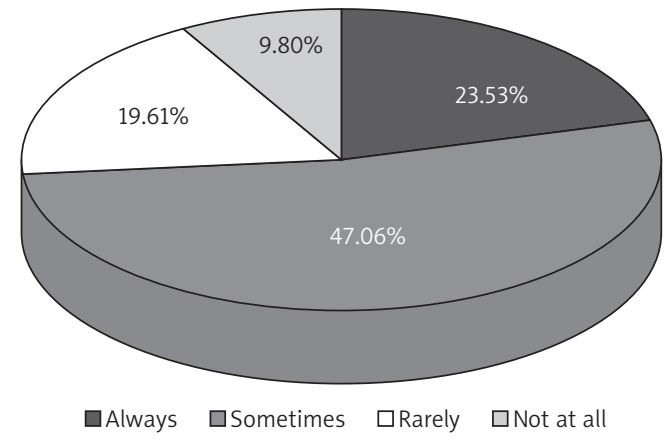

Figure 2. Because of the stoma I am ashamed of my own body 


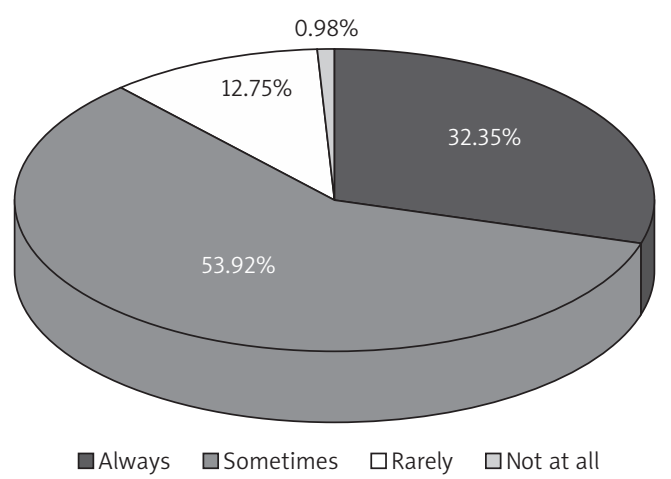

Figure 3. I am worried that my health condition is a burden for those who are close to me

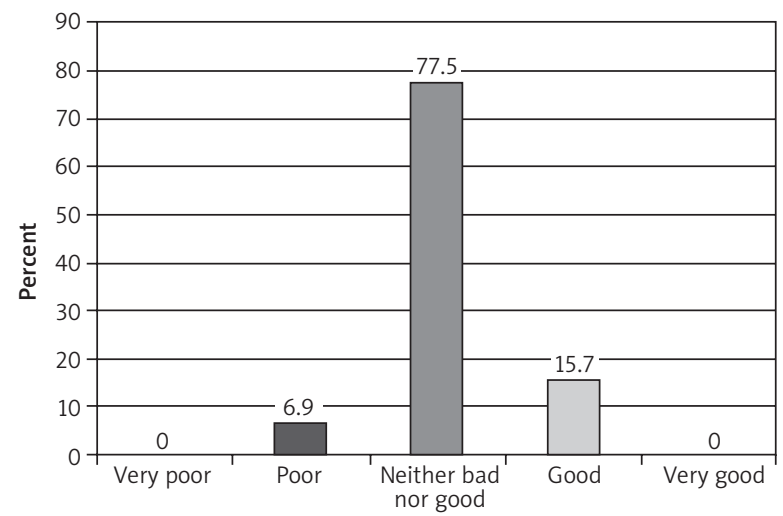

Figure 5. Presentation of data concerning the quality of life of stoma patients

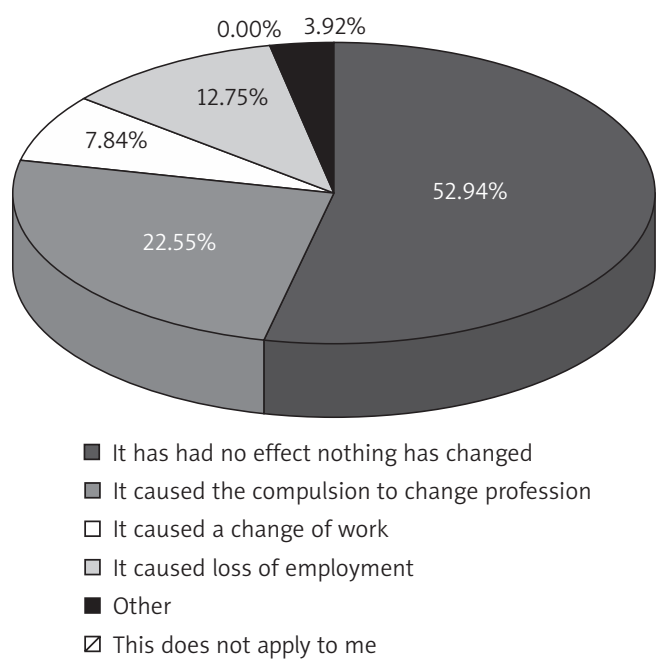

Figure 7. Has the stoma had an effect on your occupational life?

sigmoid colon and rectal cancer participating in the study verified using the standardized questionnaire scoring key is as follows: $77.5 \%(n=79)$ of respondents consider that it is at a mediocre level (neither good nor poor), $15.7 \%(n=16)$ indicate good quality, and $6.9 \%$

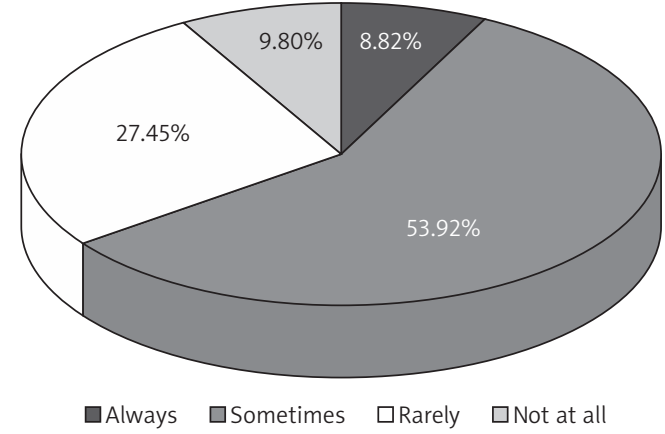

Figure 4. My stoma hinders my being with other people

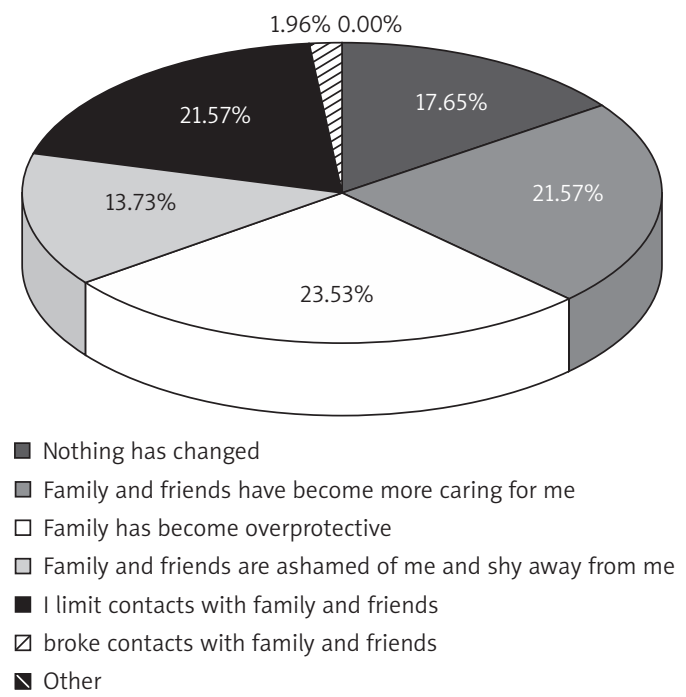

Figure 6. Has the stoma affected your family and social life?

$(n=7)$ mention a poor level of the quality of life (Figure 5). The verification showed that the quality of life of none of the respondents was at a very poor or very good level (Figure 5).

As many as $23.53 \%$ of patients $(n=24)$ consider that in the present situation their family has become overprotective, $21.57 \%(n=22)$ mention that family and friends have become caring and thoughtful, $21.57 \%$ $(n=22)$ limited contacts with family and friends, $17.65 \%(n=18)$ consider that nothing has changed, $13.73 \%(n=14)$ admit that family and friends are ashamed of them, and $1.96 \%$ of stoma patients $(n=2)$ broke contacts with their family; none of the respondents provided the answer 'other' (Figure 6).

As many as $52.94 \%$ of respondents $(n=54)$ indicated that the stoma has had no effect on their occupational life, $22.55 \%(n=23)$ reported that it caused the compulsion to change profession, $12.75 \%(n=13)$ mentioned loss of employment, 7.84\% $(n=8)$ reported a change of work, whereas only $3.92 \%(n=4)$ replied that this did not apply to them. None of the respondents provided the answer 'other' (Figure 7). 
Half of the respondents $(n=51)$ subjectively evaluated their quality of life as being at a level neither poor nor good. (Figure 8).

Based on the data obtained in the present study, a research hypothesis was posed that the occupational activity of patients with a stoma has an effect on their quality of life. The hypotheses were verified using the $\chi^{2}$ test.

As many as $77 \%$ of patients with a stoma who were occupationally active indicated a mediocre level of quality of life. Similar evaluations of the quality of life were expressed by patients who were not active occupationally. More than $78 \%$ of respondents in this group indicated that their level of life is mediocre (neither poor nor good). The calculated test value does not support the research hypothesis. Therefore, based on the research sample applied, it should be presumed that the quality of life of patients with a stoma does not depend on occupational activity (Table 1).

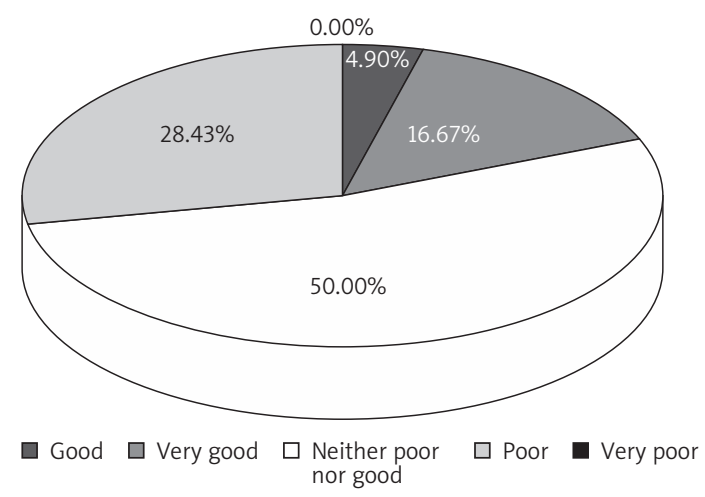

Figure 8. How do you evaluate your present quality of life? Please select one of the provided answers

The above-presented analysis of results of statistical tests performed supports the research hypothesis. The critical value $\chi^{2}$ is lower than the value calculated (for $p=0.05$; $\mathrm{d} f=4: 30.09>9.49$ ), whereas

Table 1. Quality of life of patients with a stoma according to occupational activity

\begin{tabular}{|c|c|c|c|c|}
\hline \multirow[t]{3}{*}{ Quality of life of patients with a stoma } & \multicolumn{4}{|c|}{ Occupational activity } \\
\hline & \multicolumn{2}{|c|}{ Occupationally active } & \multicolumn{2}{|c|}{ Not active occupationally } \\
\hline & $n$ & $\%$ & $n$ & $\%$ \\
\hline Very poor & 0 & 0.0 & 0 & 0.0 \\
\hline Poor & 7 & 9.5 & 0 & 0.0 \\
\hline Neither poor nor good & 57 & 77.0 & 22 & 78.6 \\
\hline Good & 10 & 13.5 & 6 & 21.4 \\
\hline Very good & 0 & 0.0 & 0 & 0.0 \\
\hline Total & 74 & 100.0 & 28 & 100.0 \\
\hline$P$-value & 0.18 & & & \\
\hline$\chi^{2}$ calculated (for $p=0.05, \mathrm{~d} f=2$ ) & 3.47 & & & \\
\hline$\chi^{2}$ table $($ for $p=0.05, \mathrm{~d} f=2$ ) & 5.99 & & & \\
\hline
\end{tabular}

Source: own study.

Table 2. Relationship between duration of the disease in patients with a stoma and their quality of life

\begin{tabular}{|c|c|c|c|c|c|c|}
\hline \multirow[t]{3}{*}{ Quality of life of patients with a stoma } & \multicolumn{6}{|c|}{ Duration of the disease } \\
\hline & \multicolumn{2}{|c|}{ Up to 6 months } & \multicolumn{2}{|c|}{$1-5$ years } & \multicolumn{2}{|c|}{$5-10$ years } \\
\hline & $n$ & $\%$ & $n$ & $\%$ & $n$ & $\%$ \\
\hline Poor & 0 & 0.0 & 6 & 18.2 & 1 & 4.5 \\
\hline Neither poor nor good & 31 & 66.0 & 27 & 81.8 & 21 & 95.5 \\
\hline Good & 16 & 34.0 & 0 & 0.0 & 0 & 0.0 \\
\hline Total & 47 & 100.0 & 33 & 100.0 & 22 & 100.0 \\
\hline$P$-value & $<0.001$ & & & & & \\
\hline$\chi^{2}$ calculated $($ for $p=0.05, \mathrm{~d} f=4)$ & 30.09 & & & & & \\
\hline$\chi^{2}$ table $($ for $p=0.05, \mathrm{~d} f=4)$ & 9.49 & & & & & \\
\hline
\end{tabular}

Source: own study. 
Table 3. Relationship between acceptance of own body image by patients with a stoma and quality of their life

\begin{tabular}{|lcccccc|}
\hline Quality of life of patients with a stoma & \multicolumn{6}{c|}{ Acceptance of own body image } \\
\cline { 2 - 7 } & \multicolumn{2}{c}{ Lack of acceptance } & Partial acceptance & Complete acceptance \\
\cline { 2 - 7 } & $n$ & $\%$ & $n$ & $\%$ & $n$ & $\%$ \\
Poor & 2 & 3.5 & 4 & 9.1 & 1 & 100.0 \\
Neither poor nor good & 45 & 78.9 & 34 & 77.3 & 0 & 0.0 \\
Good & 10 & 17.5 & 6 & 13.6 & 0 & 0.0 \\
Total & 57 & 100.0 & 44 & 100.0 & 1 & 100.0 \\
P-value & 0.005 & & & & & \\
$\chi^{2}$ calculated (for $\left.p=0.05, \mathrm{~d} f=4\right)$ & 15.08 & & & & & \\
$\chi^{2}$ table (for $\left.p=0.05, \mathrm{~d} f=4\right)$ & 9.49 & & & & \\
\hline
\end{tabular}

Source: own study.

Table 4. Relationship between marital status of patients with a stoma and quality of life

\begin{tabular}{|lcccccc|}
\hline Quality of life of patients with a stoma & \multicolumn{9}{c}{ Marital status } \\
\cline { 2 - 8 } & \multicolumn{2}{c}{ Never married } & \multicolumn{2}{c|}{ Married } & \multicolumn{2}{c|}{ Widowed } \\
\cline { 2 - 8 } & $n$ & $\%$ & $n$ & $\%$ & $n$ & $\%$ \\
Poor & 0 & 0.0 & 7 & 8.9 & 0 & 0.0 \\
Neither poor nor good & 1 & 50.0 & 60 & 75.9 & 18 & 85.7 \\
Good & 1 & 50.0 & 12 & 15.2 & 3 & 14.3 \\
Total & 2 & 100.0 & 79 & 100.0 & 21 & 100.0 \\
$P$-value & 0.40 & & & & & \\
$\chi^{2}$ calculated (for $\left.p=0.05, \mathrm{~d} f=4\right)$ & 3.98 & & & & & \\
$\chi^{2}$ table (for $\left.p=0.05, \mathrm{~d} f=4\right)$ & 9.49 & & & & \\
\hline
\end{tabular}

Source: own study.

$p<0.001$ means that the observed phenomenon is highly significant statistically. The above table shows that the shorter the duration of the disease, the more often the patients evaluate their quality of life as being at a good level. Thus, it should be presumed that, based on the research sample applied, the quality of life of patients with a stoma depends on the duration of the disease (Table 2, Figure 2).

The calculated value of $\chi^{2}$ is higher than the critical value (for $p=0.05$; $\mathrm{d} f=4: 30.09>9.49$ ); therefore, there are no grounds for accepting the hypothesis that acceptance of own body image by patients with a stoma has an effect on their overall evaluation of the quality of life.

In addition, the calculated value is $p=0.005$, which means that the observed phenomenon is highly significant statistically (Table 3, Figure 3).

Irrespective of marital status, the majority of respondents evaluated their quality of life as being at a mediocre level, 'neither poor nor good'. Therefore, based on the research group applied and the statistical test, the posed hypothesis should be rejected and, at the same time, it should be presumed that the quality of life of patients with a stoma does not depend on marital status (Table 4, Figure 4).

It was assumed that the quality of life of patients with a stoma depends on support provided by various people, such as family, friends, or other patients with the same disease. The results of the study show that there are no grounds for accepting such a hypothesis, because the value is $p=0.24$, which means that if the relationship between people providing assistance to patients with a stoma and their quality of life were accepted, the risk of committing an error would be $24 \%$. Thus, it should be presumed that, based on the research sample applied, the quality of life of patients with a stoma does not depend on others who help them and support them in the disease (Table 5).

\section{Discussion}

The formation of an intestinal stoma is associated with many multidirectional consequences for the patient, as well as for the patient's family, leading to 
Table 5. Relationship between support by others for patients with a stoma and the quality of life

\begin{tabular}{|c|c|c|c|c|c|c|c|c|c|c|}
\hline \multirow[t]{3}{*}{ Quality of life of patients with a stoma } & \multicolumn{10}{|c|}{ Assistance provided for patients with a stoma } \\
\hline & \multicolumn{2}{|c|}{ Family } & \multicolumn{2}{|c|}{ Wife } & \multicolumn{2}{|c|}{ Children } & \multicolumn{2}{|c|}{ Nobody } & \multicolumn{2}{|c|}{$\begin{array}{l}\text { Other stoma } \\
\text { patients }\end{array}$} \\
\hline & $n$ & $\%$ & $n$ & $\%$ & $n$ & $\%$ & $n$ & $\%$ & $n$ & $\%$ \\
\hline Poor & 4 & 9.8 & 2 & 9.1 & 1 & 11.1 & 0 & 0.0 & 0 & 0.0 \\
\hline Neither poor nor good & 31 & 75.6 & 16 & 72.7 & 8 & 88.9 & 13 & 68.4 & 11 & 100.0 \\
\hline Good & 6 & 14.6 & 4 & 18.2 & 0 & 0.0 & 6 & 31.6 & 0 & 0.0 \\
\hline Total & 41 & 100.0 & 22 & 100.0 & 9 & 100.0 & 19 & 100.0 & 11 & 100.0 \\
\hline$P$-value & 0.24 & & & & & & & & & \\
\hline$\chi^{2}$ calculated (for $p=0.05, \mathrm{~d} f=10$ ) & 10.42 & & & & & & & & & \\
\hline$\chi^{2}$ table $($ for $p=0.05, \mathrm{~d} f=10)$ & 15.51 & & & & & & & & & \\
\hline
\end{tabular}

Source: own study.

profound changes in the functioning and quality of life. Surgical procedures ending with the construction of an intestinal stoma are a turning point in the life of the majority of patients, exert a negative effect on self-evaluation and give the feeling of disability. Patients with a stoma require professional and thoughtful care from the entire therapeutic team, aimed at an improvement in the quality of life, which is provided based on the problems recognized in the area of functioning of the given group of patients. Therefore, the undertaking of studies of the quality of life is not only the manifestation of concern about the patient's wellbeing, but also an engagement of professionals in many medical and paramedical specialisations on behalf of improvement of his/her situation [10, 11].

The formation of an intestinal stoma has an effect on the psychosocial functioning of patients and their quality of life. Together with the construction of the stoma, there occur various types of behaviour, such as patient's withdrawal, development of sub-depressive symptoms, including clinical depression, directing anger against other people, as well as other disorders which negatively affect the process of the patient's adaptation to a 'new' life. In addition, there occurs fear of recurrence of the cancerous disease. Each patient and his/her family are afraid of the challenge which is self-care and daily living with the intestinal stoma [12-14]. In this case, health becomes the most precious value, which is simultaneously considered the most important component of the quality of life [15-19].

Studies concerning the recognition of factors conditioning the functioning of this group of patients have been undertaken for many years. Knowledge of these factors may, to a great extent, contribute to an improvement in the care of patients with an intestinal stoma and the quality of life [20, 21]. Analysis of the results of our studies shows that the quality of life reported by the respondents and validated by means of directly asked question in $50 \%$ of patients is at a medio- cre level (neither poor nor good), in $28 \%$ at a poor level, in $17 \%$ at a very poor level, whereas a good quality of life was indicated by only $5 \%$ of patients in the study. None of the respondents indicated a very good quality. Similar studies concerning the quality of life were conducted by Golicki et al. [22], the results of which are similar to those obtained in the present study. In their studies, as in the present study, the quality of life was investigated using the standardized questionnaire Stoma QoL. Studies conducted by Wiraszka using the Polish version of the questionnaire for evaluating cancer therapy (FACTC), similar to our studies, confirm a low evaluation of sex life by patients with an intestinal stoma [23]. In our study, $80 \%$ of respondents admitted that because of the stoma they are ashamed of their own body image; many of them avoid physical contact with friends and acquaintances, and in this way lose social contacts. The formation of a stoma also has an effect on the socio-economic sphere of life. The results obtained in the current study corroborate those from the study by Ponczek et al. [24] carried out during 1997-2001, in which the great majority of patients also mentioned financial difficulties. The results of our study indicate that stoma also affects family and social life. The respondents indicated that the attitude of significant others and acquaintances towards them has changed in the present situation. Approximately 95\% of respondents reported that relations between them and family or acquaintances are at a very good level. A similar result was obtained in the studies by Wirasz$\mathrm{ka}$, where the study group evaluated family relations and acceptance of a patient with an intestinal stoma in very positive terms [23].

\section{Conclusions}

The quality of life of patients with an intestinal stoma depends on the degree of acceptance of the stoma and the present body image. The higher the level 
of acceptance of the stoma, the lower the quality of life. The quality of life of patients with an intestinal stoma depends on the duration of the disease and duration of life with the stoma. The longer the duration of the disease, the worse the quality of life. There is no relationship between the degree of acceptance of the stoma by the patient and support provided by family and friends. Each patient must independently go through the process of acceptance of the 'present me'. The stoma exerts an effect on the quality of patients' sex life. The patients mention that their sexual attractiveness has considerably deteriorated, compared to that before the stoma.

\section{Conflict of interest}

The authors declare no conflict of interest.

\section{References}

1. Banaszkiewicz Z, Szewczyk M, Cieżniakowska K, Jawień A. Jakość życia osób ze stomią jelitową. Współcz Onkol 2007; 11: 17-25.

2. Leyk M, Książek J, Piotrkowska R, Terech S, Kruk A. Jakość życia osób z wyłonioną kolostomią. Pielęg Chir Angiol 2010; 3: 77-84.

3. Grumann MM, Noack EM, Hoffmann IA, Schlag PM. Comparison of quality of life in patients undergoing abdominoperineal extirpation or anterior resection for rectal cancer. Ann Surg 2001; 233: 149-56.

4. Szczepkowski M. Stomia jelitowa - wyzwanie nie tylko dla chirurga. Proktol Lek Rodz 2004; 4: 57-69.

5. Coons SJ, Chongpison Y, Wendel CS, Grant M, Krouse RS. Overall quality of life and difficulty paying for ostomy supplies in the VA Ostomy Health-Related Quality of Life Study: an exploratory analysis. Med Care 2007; 45: 891-5.

6. Dowbór-Dzwonka A, Nowicki A. Rola pielęgniarki w opiece nad chorym ze stomią. In: Pielęgniarstwo onkologiczne. Nowicki A (red.). Termedia, Poznań 2009; 233-53.

7. Sprangers MAG, Taal BG, Aaronson NK, te Velde A. Quality of life in colorectal cancer: stoma vs nonstoma patients. Dis Colon Rectum 1995; 38: 361-9.

8. Szepkowski M. Dobra stomia. Post Nauk Med 2006; 19: 240-50.

9. http://www.coloplast.pl/ Avaialbe at: 2014.12.12.

10. Głuszek S, Stanisławek J. Adaptacja chorego ze stomią w okresie okołooperacyjnym. Niepełnosprawność wyzwaniem dla opieki interdyscyplinarnej. Zeszyty Naukowe WSBIP 2003; 119-25.

11. Bosshardt TL. Outcomes of ostomy procedures in patients aged 20 years and older. Arch Surg 2003; 138: 1077-82.

12. Mitchell KA, Rawl SM, Schmidt CM, Grant M, Ko CY, Baldwin CM, Wendel C, Krouse RS. Demographic, clini$\mathrm{cal}$, and quality of life variables related to embarrassment in veterans living with an intestinal stoma. J Wound Ostomy Continence Nurs 2007; 34: 524-32.

13. Głuszek S. Problemy psychologiczne chorych ze stomią. VII Sympozjum PKK, Kielce, 23-25.10.2008. Proktologia 2008; 9: 27.

14. Wawrzycka I, Głuszek S, Sideł Jarema E. Opieka pielęgniarska nad trudną stomią. VII Sympozjum PKK, Kielce, 23-25.10.2008. Proktologia 2008; 9: 278.
15. Pochocka L, Urbanek A. Stomia jelitowa - epidemiologia. Rys historyczny. Zasady wyłaniania i rodzaje stomii jelitowych. Probl Hig Epidemiol 2014; 3: 586-90.

16. Nugent KP, Daniels P, Stewart B, Patankar R, Johnson CD. Quality of life in stoma patients. Dis Colon Rectum 1999; 42: $1569-74$.

17. Głuszek S. Adaptacja chorego ze stomią do nowej sytuacji zdrowotnej. Proktologia 2003; Numer specjalny: 37-41.

18. Klusek J, Głuszek S, Kozieł D. Co nowego w profilaktyce nowotworów układu pokarmowego - przegląd piśmiennictwa 2009-2010. Prz Gastroenterol 2010; 6: 78-84.

19. Piaszczyk D, Schabowski J. Problemy medyczne i społeczne pacjentów ze stomią należących do POL-ILKO. Med Ogólna Nauk Zdrow 2014; 20: 384-9.

20. Bazaliński D, Barańska B, Cipora E. Stomia jelitowa nie musi być przyczyną niepełnosprawności. Med Rodz 2006; 3: 58-63

21. Stodolsa A, Szewczyk MT, Banaszkiewicz Z, Jawień A. Różnorodność problemów pielęgnacyjnych u wybranych pacjentów ze stomią jelitową. Post Med Klin Wojsk 2002; 2: 25-9.

22. Golicki D, Styczeń P, Szczepkowski M. Jakość życia pacjentów ze stomią jelitową w Polsce badania przekrojowe z wykorzystaniem kwestionariusza WHOOOL-BREF. Prz Epidemiol 2013; 67: 589-93.

23. Wiraszka G. Problemy funkcjonowania chorych z kolostomią wytworzoną po operacyjnym leczeniu raka jelita grubego na podstawie badań HRQO. Probl Pielęg 2007; 1: 1-6.

24. Ponczek D, Nowicki A, Zegarski W. Ocena jakości życia chorych leczonych chirurgicznie z powodu raka odbytnicy w aspekcie czynników społeczno-demograficznych. Współcz Onkol 2006; 10: 164-70.

\section{Address for correspondence:}

\section{Monika Pietrzak MD}

Faculty of Medicine and Health Science

Jan Kochanowski University

al. IX Wieków Kielc 19, 25-317 Kielce, Poland

Phone: +48 693716969

E-mail: monikapierzak03@o2.pl 